\title{
PENGARUH MOTIVASI, KEPUASAN KERJA DAN KOMITMEN KERJA TERHADAP KINERJA PEGAWAI
}

\author{
Udik Yudiono, Farida Marwia \\ Universitas Kanjuruhan Malang
}

\begin{abstract}
Asbtrak: Tujuan dari penelitian ini adalah: (1) Mengetahui pengaruh secara parsial motivasi, kepuasan kerja dan komitmen terhadap kinerja pegawai pada Sekolah Menengah Kejuruan Muhammadiyah 7 Gondanglegi Kabupaten Malang; (2) Mengetahui pengaruh secara simultan motivasi, kepuasan kerja dan komitmen kerja terhadap kinerja pegawai pada Sekolah Menengah Kejuruan Muhammadiyah 7 Gondanglegi Kabupaten Malang. Metode yang digunakan pada penelitian ini adalah penelitian survey dengan pendekatan deskriptif kuantitatif, Penelitian survey adalah penelitian yang dilakukan pada populasi besar maupun kecil, tetapi data yang dipelajari adalah data dari sampel yang diambil dari populasi tersebut. Sehingga kemudian ditemukan kejadian-kejadian relatif, distribusi, dan hubungan antar variabel sosiologis maupun psikologis, dan dilakukan untuk mengambil suatu generalisasi dari sebuah sampel ke dalam populasi. Hasil penelitian menunjukkan bahwa; (1) Secara parsial atau sendiri-sendiri antara variabel motivasi kerja (X1), kepuasan kerja (X2) dan komitmen terhadap (X3) semuanya berpengaruh secara signifikan terhadap kinerja pegawai (Y) pada Sekolah Menengah Kejuruan Muhammadiyah 7 Gondanglegi Kabupaten Malang. Hal ini dibuktikan pada hasil perhitungan software SPSS versi 21 bahwa motivasi kerja (X1) berpengaruh terhadap kinerja pegawai (Y). Sedangkan kepuasan kerja (X2) dan komitmen kerja (X3) secara parsial juga berpengaruh terhadap kinerja pegawai (Y); (2) Ada pengaruh secara simultan atau bersama-sama antara variabel motivasi kerja (X1), kepuasan kerja (X2) dan komitmen pegawai (X3) terhadap kinerja pegawai (Y) pada Sekolah Menengah Kejuruan Muhammadiyah 7 Gondanglegi Kabupaten Malang.
\end{abstract}

Kata kunci: Motivasi kerja, kepuasan kerja, komitmen pegawai, kinerja pegawai

\section{PENDAHULUAN}

Kinerja tenaga pendidik (guru) dan tenaga kependidikan (staf) memegang peranan. penting dalam suatu lembaga pendidikan khususnya SMK sebab dalam rangka pencapaian tujuan dari suatu organisasi dibutuhkan dukungan tenaga pendidik dan kependidikan yang kompeten di bidangnya. Pelayanan administrasi dengan kinerja yang lebih baik secara maksimal dapat dicapai dalam suatu organisasi sesuai dengan wewenang dan tanggung jawab masingmasing pegawai dalam mewujudkan tujuan lembaga pendidikan.

Kinerja dari seorang pegawai akan dipengaruhi oleh banyak sekali faktor, tetapi yang dibahas dalam permasalahan ini hanya berfokus pada masalah motivasi, kepuasan kerja, dan komitmen kerja,yang akan memberikan dampak pada hasil kinerja pegawai dalam mencapai tujuan yang telah ditetapkan pada
Sekolah Menengah Kejuruan Muhammadiyah 7 Gondanglegi Kabupaten Malang.

Motivasi merupakan faktor yang menimbulkan semangat atau dorongan serta bisa juga menggerakkan seseorang untuk melakukan sesuatu. Semangat kerja dalam diri pegawai untuk melakukan sesuatu demi memperoleh apa yang menjadi kebutuhan pegawai dan untuk mencapai tujuan dari lembaga pendidikan tersebut. Fenomena-fenomena yang berkaitan dengan motivasi dapat dilihat dari sikap yang diperlihatkan pegawai seperti kurangnya kebebasan dalam mengemuka-kan ide-ide ataupun pendapat dan insentif yang diterima tidak sesuai dengan porsi kerja dan kemampuan yang ada.

Kepuasan kerja yang dimiliki oleh seorang pegawai akan memperlihatkan sikap yang positif terhadap pekerjaan dalam bekerja, sedangkan pegawai yang tidak puas akan memperlihatkan sikap yang negatif terhadap 
pekerjaan itu sendiri. Kepuasan kerja merupakan hasil dari berbagai sikap (attitude) bagi seorang pegawai, jika suatu pekerjaan sesuai dengan kepentingan dan harapan maka semakin tinggi tingkat kepuasan yang dirasakan oleh pegawai demikian pula sebaliknya. Fenomena yang berkaitan dengan kepuasan kerja pegawai pada Sekolah Menengah Kejuruan Muhammadiyah 7 Gondanglegi dapat dilihat dari beban pekerjaan yang tidak merata, kurang adanya kerjasama di antara sesama pegawai dan kurangnya masukan dari pimpinan, seberapa baik hasil kerja yang telah diselesaikan oleh pegawai dan lain-lain.

Komitmen kerja juga sangat memengaruhi kinerja pegawai, dimana komitmen merefleksikan tingkat identifi-kasi dan keterlibatan individu dalam pekerjaannya, bagi para guru dan staf misalnya diproses belajar mengajar, tanggung jawab dalam pekerjaan, dan ketidaksediaannya untuk meninggalkan lembaga atau tetap bertahan di dalam institusi. Dengan komitmen yang tinggi tentunya akan meningkatkan kinerja guru dan staf dalam bidang pemahaman dan pengawasan tugas, disiplin, mampu memecahkan masalah, mampu bekerjasama, tepat dalam mengambil keputusan, menyelesaikan semua tanggung-jawab yang telah dibebankan.

Tujuan di dalam penelitian ini adalah untuk meningkatkan kinerja pegawai di Sekolah Menengah Kejuruan Muhammadiyah 7 Gondanglegi, yang mana hal ini akan sangat berguna bagi pihak sekolah dan bagi siswa itu sendiri. Sedangkan tujuan khusus di dalam penelitian ini adalah untuk mengetahui faktor-faktor mana yang berpengaruh terhadap kinerja pegawai di Sekolah Menengah Kejuruan Muhammadiyah 7 Gondanglegi. Setelah mengetahui faktor mana yang paling berpengaruh maka pihak sekolah bisa mengimplementasikannya di dalam kebijakan-kebijakan sekolah agar nanti bisa digunakan untuk memaksimalkan kinerja pegawai.

Menurut Robin (2003:133) Pengertian motivasi adalah kemauan untuk berusaha ketingkat yang lebih tinggi menuju tercapainya tujuan organisasi tanpa mengabaikan kemauan untuk memperoleh kepuasan dalam pemenuhan kebutuhan-kebutuhan pribadi. Tujuan organisasi bisa bermacam-macam dan berbeda, tergantung dari organisasi jenis apa yang berdiri.

Sementara Gibson (2000:138) mendefinisikan motivasi adalah kekuatan yang mendorong seorang pegawai yang dapat menimbulkan dan mengarahkan perilaku. Motivasi kerja diartikan sebagai sesuatu yang menimbulkan dorongan atau semangat kerja, atau dengan kata lain pendorong semangat kerja.

Beberapa faktor yang dapat mempengaruhi motivasi kerja menurut Mathis (2001:276) adalah atasan, rekan kerja, sarana fisik, kebijaksanaan dan peraturan, imbalan jasa uang dan non uang, jenis pekerjaan dan tantangan. Dari pendapat ini dapat disimpulkan bahwa lingkungan sangat mempengaruhi motivasi pegawai.

Motivasi merupakan dorongan yang datang dari dalam diri pegawai yang mengaktifkan, menggerakkan serta menga-rahkan perilaku untuk mencapai tujuan karena itu kunci untuk mengerti motivasi adalah memahami hubungan kebutuhan, dorongan dan tujuan (Rivai 2006:148), dorongan adalah motif dari dalam diri manusia untuk bertindak atau berprilaku, menggerakkan adalah menempatkan diri pada kelompok agar berkerja secara sadar untuk mencapai suatu tujuan yang telah ditetapkan sesuai dengan perancanaan dan pola organisasi. Mengarahkan perilaku adalah suatu konstruksi yang mengaktifkan dan cara memberi dorongan atau daya pada organisasi untuk melakukan aktivitas.

Kepuasan kerja merupakan sikap dalam diri seorang pegawai yang berkaitan dengan 
pekerjaan dan merupakan kecen-derungan perilaku pegawai dalam meng-aplikasikan seluruh kemampuan kerja pegawai melalui sikap dan kondisi dalam bekerja demi mencapai tujuan akhir suatu organisasi untuk masa yang akan datang.

Menurut Kuswadi (2004), menyata-kan bahwa "Kepuasan karyawan merupa-kan ukuran sampai seberapa jauh pe-rusahaan dapat memenuhi harapan karyawannya. Menurut pendapat Robbins (2006), bahwa "kepuasan kerja adalah sikap umum individu dalam melaksanakan pekerjaannya. Pekerjaan membutuhkan interaksi dengan rekan kerja dan pim-pinan, mematuhi peraturan-peraturan dan kebijakan organisasi, memenuhi standart kinerja, dan hidup dengan suasana kerja yang ideal".

Menurut Fathoni (2006), kepuasan kerja adalah sikap emosional yang menyenangkan dan mencintai pekerjaan-nya. Sikap ini dapat dicerminkan pada moral kerja, kedisiplinan, dan prestasi kerja. Hal ini akan membuat para pegawai termotivasi untuk bekerja dengan optimal yang pada akhirnya tujuan organisasi dapat terwujud dengan tingkat efisien dan aktifitas yang tinggi. Menurut Tiffin (1958) dalam Sutrisno (2009), menyatakan bahwa "Kepuasan kerja berhubungan erat dengan sikap dari karyawan terhadap pekerjaannya sendiri, situasi kerja, kerjasama antara pimpinan dengan sesama rekan kerja".

Seseorang cenderung bekerja dengan penuh semangat apabila kepuasan dapat diperolehnya dari pekerjaannya dan kepuasan kerja merupakan kunci pendorong moral, kedisiplinan dan prestasi kerja pegawai dalam mendukung terwujudnya tujuan perusahaan (Hasibuan, 2005).

Strauss dan Sayles (1963) dalam Handoko (2001), menyatakan bahwa: Kepuasan juga penting untuk diaktualisasikan sebab jika seseorang tidak memperoleh kepuasan kerja maka orang tersebut tidak akan mencapai kematangan psikologis yang akhirnya akan menjadi prustasi. Dalam keadaan seperti ini maka sesorang akan cepat lelah dan merasa bosan, memiliki standart kerja yang rendah, sering melamun, emosi tidak stabil, sering tidak masuk kerja, dan melakukan kesibukan yang tidak berhubungan dengan pekerjaan yang menjadi tanggug jawabnya. Tetapi jika seseorang mendapat kepuasan kerja biasanya memiliki tingkat disiplin dan kinerja yang lebih baik dan mampu berprestasi lebih baik. Oleh karena itu, kepuasan kerja memiliki arti penting baik bagi karyawan maupun organisasi, terutama karena menciptakan keadaan positif di dalam lingkungan kerja perusahaan.

Mowday (1982:64) mendefenisikan komitmen kerja sebagai kekuatan relatif dari identifikasi individu dan keterlibatan-nya dengan organisasi kerja. Salah satu cara untuk mengukur kualitas pengelolaan suatu perusahaan adalah komitmen karyawannya. Mulyadi (2001) mendefinisikan bahwa komitmen adalah kesediaan personel untuk menginvestasikan perhatian dan pengetahuannya kepada pekerjaannya. Alwi (2001) berpendapat komitmen adalah bentuk loyalitas yang lebih konkrit yang dapat dilihat dari sejauhmana karyawan mencurahkan perhatian, gagasan dan tanggungjawabnya dalam upaya perusahaan mencapai tujuan. Atmosoeprapto (2002) mengatakan komit-men biasa diartikan "keterikatan" dan menyangkut dua unsur yakni:

1. confidence yakni ukuran keyakinan diri seseorang atau rasa mampu melakukan suatu tugas dengan baik tanpa banyak diawasi; dan

2. motivation yakni minat dan antusias seseorang untuk melakukan suatu tugas dengan baik.

Komitmen dibagi menjadi dua bagian besar yakni: 
1. Komitmen eksternal dibentuk oleh lingkungan kerja dan muncul karena adanya tuntutan terhadap penyelesaian tugas dan tanggung jawab. Peran manajer dan supervisor sangat vital dalam menentukan timbulnya komitmen ini karena belum adanya suatu kesadaran individual atas tugas yang diberikan;

2. Komitmen internal merupakan komitmen yang berasal dari diri seseorang untuk menyelesaikan berbagai tugas, tanggungjawab dan wewenang berdasarkan pada alasan dan motivasi yang dimilikinya. Munculnya komitmen internal sangat ditentukan oleh kemampuan pemimpin dan lingkungan organisai dalam menumbuhkan sikap dan perilaku professional dalam menyelesaikan tanggungjawab perusahaan.

Karyawan yang berkomitmen akan mencurahkan energi emosional dan perhatiannya ke perusahaan. Komitmen dapat dideteksi dari bagaimana karyawan berhubungan satu dengan lainnya dan dari bagaimana perasaan mereka terhadap perusahaan. Faktor-faktor komitmen orga-nisasi dalam Organizational Commitment Questionare terdiri atas tiga komponen yaitu:

1. Affective (Emotional Attachment) ber-kaitan dengan emosional, identifikasi dan keterlibatan pegawai di dalam suatu organisasi;

2. Continuance (Cost of leaving) yakni persepsi pegawai tentang kerugian yang akan dihadapinya jika ia meninggalkan organisasi;

3. Normative (Obligation to stay) merupakan perasaan-perasaan pegawai tentang kewajiban yang harus diberikan kepada organisasi.

Komitmen karyawan berkaitan dengan bagaimana karyawan akan berperilaku dalam perusahaan. Makna komitmen organisasi adalah tingkat kepercayaan dan penerimaan tenaga kerja terhadap tujuan organisasi dan mempunyai keinginan untuk tetap ada di dalam organisasi yang pada akhirnya tergambar dalam statistik ketidakhadiran (absen) serta keluar masuk tenaga kerja (turnover). Menurut Luthans (1995) makna dari komitmen organisasi adalah:

$>$ Suatu keinginan yang kuat untuk menjadi anggota dari organisasi tertentu;

$>$ Keinginan menuju level keahlian tinggi atas nama organisasi dan

$>$ Suatu kepercayaan tertentu di dalam penerimaan terhadap nilai-nilai dan tujuan organisasi tersebut.

Seorang tenaga kerja yang merasa terikat dengan organisasi akan merasa enggan untuk menjadi anggota organisasi, percaya akan organisasi dan memandang baik tentang organisasi yang terwujud dalam perilaku mewakili organisasi dalam lingkungan luar organisasi serta melakukan hal-hal terbaik untuk organisasi.

Para ahli manajemen sumber daya manusia dan perilaku organisasi menjelas-kan konsep kinerja (performance) dengan menggunakan ungkapan bahasa dan tinjauan dari sudut pandang yang berbeda-beda namun makna yang terkandung pada hakekatnya sama, yaitu catatan outcome yang dihasilkan dari fungsi suatu pekerjaan atau kegiatan tertentu selama suatu periode waktu tertentu.

Kinerja pegawai merupakan aspek yang penting dalam manajemen sumber daya manusia beberapa pengertian yang dikemukakan adalah sebagai berikut: Sedarmayanti (2007:70) menyatakan bahwa kinerja merupakan sistem yang digunakan untuk menilai dan mengetahui apakah seorang karyawan telah melaksanakan pekerjaannya secara keseluruhan, atau merupakan perpaduan dari hasil kerja (apa yang harus dicapai seseorang) dan kompetensi (bagaimana seseorang mencapainya). Mangkunegara (2006:64) menyatakan bahwa 
kinerja sumber daya manusia merupakan istilah dari kata Job Performance atau Actual Performance (Prestasi Kerja) adalah Hasil kerja secara kualitas dan kuantitas yang dicapai oleh seseorang pegawai di dalam melaksanakan tugas sesuai dengan tanggung jawab yang diberikan untuk mencapai tujuan orga-nisasi. Kualitas adalah kemampuan yang dimiliki pegawai yang lebih berorientasi pada intelejensi dan daya pikir serta penguasaan ilmu yang luas yang dimiliki pegawai. Kuantitas adalah jumlah kerja yang dilaksanakan oleh seseorang pegawai dalam suatu periode tertentu. Tujuan organisasi adalah keadaan atau tujuan yang ingin dicapai oleh organisasi di waktu yang akan datang melalui kegiatan organisasi.

Kustriyanto dalam Mangkunegara (2006:98) juga menyatakan bahwa kinerja adalah perbandingan hasil yang dicapai dengan peran serta tenaga kerja persatuan waktu. Selanjutnya Handoko (2001:76) menyatakan bahwa kinerja (perfomance appraisal) adalah proses melalui mana organisasi-organisasi mengevaluasi atau menilai prestasi kerja karyawan dimana dalam kegiatan ini dapat memperbaiki keputusan-keputusan personalia dan memberikan umpan balik kepada para karyawan tentang pelaksanaan kerja mereka.

Rivai (2003:175) menyatakan bahwa; prestasi kerja atau kinerja adalah kontribusi yang dapat diberikan oleh suatu bagian, dalam pencapaian tujuan perusa-haan. Oleh karena itu kontribusi tersebut perlu diukur seberapa besar pengaruhnya terhadap nilai yang diberikannya dalam mencapai tujuan perusahaan. Proses penilaian kinerja sangat berhubungan dengan keahlian karyawan. Dalam perkem-bangan yang kompetitif dan mengglobal, perusahaan membutuhkan karyawan yang berprestasi tinggi. Pada saat yang sama karyawan memerlukan umpan balik atas kinerja mereka sebagai pedoman bagi tindakantindakan mereka di masa yang akan datang. Oleh karena itu, penilaian seharusnya menggambarkan kinerja karyawan.

\section{METODE PENELITIAN}

Metode yang digunakan penelitian ini merupakan penelitian survey dengan pendekatan deskriptif kuantitatif. Berdasar-kan sifat penelitiannya penelitian ini bersifat deskriptif explanatory yaitu menguraikan dan menjelaskan pengaruh motivasi, kepuasan kerja dan komitmen kerja terhadap kinerja pegawai.

Populasi di dalam penelitian ini adalah para pegawai di SMK Muhammadiyah 7 Gondanglegi Malang. Adapun lokasi di dalam penelitian ini adalah pada SMK Muhammadiyah 7, Jalan KH. Ahmad Dahlan No. 20 Putat Kidul, Gondanglegi, Malang yang terdiri atas guru dan karyawan yang masih aktif jumlahnya ada 97 orang. Penelitian ini dilakukan selama kurun waktu empat bulan.

Teknik Sampling dalam penelitian ini adalah probability sampling karena memberikan peluang yang sama bagi setiap anggota populasi namun, secara spesifik menggunakan teknik proporsional random sampling karena anggota populasi yang heterogen, teknik ini dilakukan dengan cara pengambilan sampel secara acak.

Umar (2002) menyatakan bahwa untuk menentukan minimal jumlah sampel yang dibutuhkan jika ukuran populasi diketahui maka digunakan rumus Slovin.

$n_{\text {sampel }}=\frac{N}{1+N d^{2}}$

Keterangan :

$\mathrm{n}_{\text {sampel }}=$ Jumlah sampel yang dijadikan responden

$\mathrm{N}=$ Jumlah populasi

$\mathrm{d}^{2} \quad=$ Adalah kuadrat dari indeks 0,10

$n_{\text {sampel }}=\frac{97}{1+(97) 0,01}=49,23$ dibulatkan menjadi 50 orang 
Jadi sampel yang diambil di dalam penelitian ini adalah 50 orang, sampel nanti diambil secara acak dan setiap orang punya kesempatan yang sama.

Data di ambil dengan observasi, wawancara dengan pengamatan langsung, dokumentasi dari aktifitas keseharian yang dilakukan para pegawai di sekolah ini. Tentang aktifitas motivasi kerja, kepuasan kerja, komitmen kerja dan kinerja pegawai yang dilakukan sehari-hari diisikan sendiri oleh responden pada sebuah lembar kuisioner.

\section{HASIL DAN PEMBAHASAN}

Jumlah responden di dalam penelitin ini adalah 50 orang, responden di ambil secara acak dari populasi di sekolah SMK Muhammadiyah 7 Gondanglegi Kabupaten Malang. Adapun rekapitulasi jumlah dan jenis gendernya bisa dilihat pada tabel di bawah ini.

\section{Tabel 4.1 Rekapitulasi Jumlah Gender}

\begin{tabular}{|c|c|c|}
\hline \multicolumn{1}{|c|}{ Jenis kelamin } & Jumlah responden & Prosentase \\
\hline Perempuan & 22 responden & $44 \%$ \\
\hline Laki-laki Jumlah & 28 responden & $56 \%$ \\
\hline \multicolumn{1}{|c|}{ Ju responden } & $100 \%$ \\
\hline
\end{tabular}

Sumber: Lampiran Distribusi Frekuensi

Dari data di atas bisa diketahui bahwa responden di dalam penelitian ini yang berjenis kelamin perempuan adalah 22 orang atau $44 \%$, sedangkan sisanya 28 orang atau $56 \%$ berjenis kelamin laki-laki. Sedangkan pembagian masa kerja pegawai bisa dilihat pada tabel di bawah ini.

Tabel 4.2 Rekapitulasi Masa Kerja

\begin{tabular}{|c|l|c|c|}
\hline Range Masa Kerja & \multicolumn{1}{|c|}{ Kriteria } & Jumlah responden & Prosentase \\
\hline 1 th -3 th & Masa kerja baru & 18 responden & $36 \%$ \\
\hline 4 th -6 th & Masa kerja sedang & 8 responden & $16 \%$ \\
\hline 7 th -9 th & Masa kerja lama & 4 responden & $8 \%$ \\
\hline$\geq 10$ th & Masa kerja sangat lama & 20 responden & $40 \%$ \\
\hline & & 50 responden & $100 \%$ \\
\hline
\end{tabular}

\section{Sumber: Lampiran Distribusi Frekuensi}

Dari data di atas dapat diketahui jumlah responden pada SMK Mu-hammadiyah 7 Gondanglegi Kabupaten Malang degan masa kerja 1th-3th kriteria pegawai baru berjumlah 18 responden atau 36\%. Pegawai dengan rentang masa kerja 4th-6th kriteria pegawai dengan masa kerja sedang berjumlah 8 responden atau $16 \%$. Kemudian pegawai dengan rentang masa kerja 7 th- $9^{\text {th }}$ kriteria pegawai yang bekerja dengan masa kerja yang cukup lama berjumlah 4 responden atau $8 \%$. Kriteria pegawai dengan masa kerja pada kategori sangat lama range nilai $\geq 10$ th berjumlah 20 responden atau $40 \%$.

Deskripsi variabel penelitian berisi hasil rekapan dari jawaban pernyataan yang diberikan peneliti kepada responden melalui kuisioner. Kuisioner diberikan kepada res-ponden untuk melihat respon serta menggambarkan yang ada di benak responden melalui kuisioner yang diberikan oleh peneliti.

Di bawah ini adalah rekapitulasi jawaban responden dari pernyataan yang diberikan 
peneliti kepada responden tentang variabel motivasi kerja(X1).

Tabel 4.3 Deskripsi Variabel Motivasi Kerja (X1)

\begin{tabular}{|c|c|c|c|c|c|c|c|c|c|c|}
\hline \multirow{2}{*}{ Kriteria jawaban } & \multicolumn{2}{|c|}{ X1.1 } & \multicolumn{2}{|c|}{$\mathbf{X 1 . 2}$} & \multicolumn{2}{|c|}{$\mathbf{X 1 . 3}$} & \multicolumn{2}{|c|}{ X1.4 } & \multicolumn{2}{|c|}{$\mathbf{X 1 . 5}$} \\
\hline & $\mathbf{F}$ & $\%$ & $\mathbf{F}$ & $\%$ & $\mathbf{F}$ & $\%$ & $\mathbf{F}$ & $\%$ & $\mathbf{F}$ & $\%$ \\
\hline Sangat setuju & 12 & $24 \%$ & 12 & $24 \%$ & 9 & $18 \%$ & 11 & $22 \%$ & 11 & $22 \%$ \\
\hline Setuju & 37 & $74 \%$ & 32 & $64 \%$ & 37 & $74 \%$ & 36 & $72 \%$ & 35 & $70 \%$ \\
\hline Netral & 1 & $2 \%$ & 7 & $14 \%$ & 4 & $8 \%$ & 3 & $6 \%$ & 4 & $8 \%$ \\
\hline Tidak setuju & 0 & $0 \%$ & 0 & $0 \%$ & 0 & $0 \%$ & 0 & $0 \%$ & 0 & $0 \%$ \\
\hline Sangat tidak setuju & 0 & $0 \%$ & 0 & $0 \%$ & 0 & $0 \%$ & 0 & $0 \%$ & 0 & $0 \%$ \\
\hline Jumlah & 50 & $100 \%$ & 50 & $100 \%$ & 50 & $100 \%$ & 50 & $100 \%$ & 50 & $100 \%$ \\
\hline Modus & 4 & & 4 & & 4 & & 4 & & 4 & \\
\hline
\end{tabular}

Sumber: Lampiran distribusi frekuensi

Di bawah ini adalah rekapitulasi diberikan peneliti kepada responden tentang jawapan responden dari pernyataan yang variabel kepuasan kerja (X2):

Tabel 4.4 Deskripsi Variabel Kepuasan Kerja (X2)

\begin{tabular}{|l|l|l|l|l|l|l|l|l|l|l|}
\hline \multirow{2}{*}{ Kriteria jawaban } & \multicolumn{2}{|c|}{ X2.1 } & \multicolumn{2}{|c|}{ X2.2 } & \multicolumn{2}{c|}{ X2.3 } & \multicolumn{2}{|c|}{ X2.4 } & \multicolumn{2}{c|}{ X2.5 } \\
\cline { 2 - 12 } & F & \% & F & \% & F & \% & F & \% & F & \% \\
\hline Sangat setuju & 7 & $14 \%$ & 12 & $24 \%$ & 8 & $16 \%$ & 17 & $28 \%$ & 13 & $26 \%$ \\
\hline Setuju & 39 & $78 \%$ & 32 & $64 \%$ & 40 & $80 \%$ & 28 & $56 \%$ & 31 & $62 \%$ \\
\hline Netral & 4 & $8 \%$ & 6 & $12 \%$ & 2 & $4 \%$ & 5 & $10 \%$ & 6 & $12 \%$ \\
\hline Tidak setuju & 0 & $0 \%$ & 0 & $0 \%$ & 0 & $0 \%$ & 0 & $0 \%$ & 0 & $0 \%$ \\
\hline Sangat tidak setuju & 0 & $0 \%$ & 0 & $0 \%$ & 0 & $0 \%$ & 0 & $0 \%$ & 0 & $0 \%$ \\
\hline Jumlah & 50 & $100 \%$ & 50 & $100 \%$ & 50 & $100 \%$ & 50 & $100 \%$ & 50 & $100 \%$ \\
\hline Modus & 4 & & 4 & & 4 & & 4 & & 4 & \\
\hline
\end{tabular}

Sumber: Lampiran distribusi frekuensi

Di bawah ini adalah rekapitulasi jawapan peneliti kepada responden tentang variabel responden dari pernyataan yang diberikan komitmen kerja (X3):

Tabel 4.5 Deskripsi Variabel Komitmen Kerja (X3)

\begin{tabular}{|l|l|l|l|l|l|l|l|l|l|l|}
\hline \multirow{2}{*}{ Kriteria jawaban } & \multicolumn{2}{|c|}{ X3.1 } & \multicolumn{2}{|c|}{ X3.2 } & \multicolumn{2}{c|}{ X3.3 } & \multicolumn{2}{|c|}{ X3.4 } & \multicolumn{2}{c|}{ X3.5 } \\
\cline { 2 - 12 } & $\mathbf{F}$ & $\mathbf{\%}$ & $\mathbf{F}$ & $\mathbf{\%}$ & $\mathbf{F}$ & $\mathbf{\%}$ & $\mathbf{F}$ & $\mathbf{\%}$ & F & \% \\
\hline Sangat setuju & 8 & $16 \%$ & 8 & $16 \%$ & 12 & $24 \%$ & 9 & $18 \%$ & 9 & $18 \%$ \\
\hline Setuju & 39 & $78 \%$ & 38 & $76 \%$ & 35 & $70 \%$ & 34 & $68 \%$ & 41 & $82 \%$ \\
\hline Netral & 3 & $6 \%$ & 4 & $8 \%$ & 3 & $6 \%$ & 7 & $14 \%$ & 0 & $0 \%$ \\
\hline Tidak setuju & 0 & $0 \%$ & 0 & $0 \%$ & 0 & $0 \%$ & 0 & $0 \%$ & 0 & $0 \%$ \\
\hline Sangat tidak setuju & 0 & $0 \%$ & 0 & $0 \%$ & 0 & $0 \%$ & 0 & $0 \%$ & 0 & $0 \%$ \\
\hline Jumlah & 50 & $100 \%$ & 50 & $100 \%$ & 50 & $100 \%$ & 50 & $100 \%$ & 50 & $100 \%$ \\
\hline Modus & 4 & & 4 & & 4 & & 4 & & 4 & \\
\hline
\end{tabular}

Sumber: Lampiran distribusi frekuensi 
Di bawah ini adalah rekapitulasi jawapan responden dari pernyataan yang diberikan peneliti kepada responden tentang variabel kinerja pegawai $(\mathrm{Y})$ :

Tabel 4.6 Deskripsi Variabel Kinerja Pegawai (Y)

\begin{tabular}{|l|l|l|l|l|l|l|l|l|l|l|}
\hline \multirow{2}{*}{ Kriteria jawaban } & \multicolumn{2}{|c|}{ Y1.1 } & \multicolumn{2}{|c|}{ Y1.2 } & \multicolumn{2}{c|}{ Y1.3 } & \multicolumn{2}{c|}{ Y1.4 } & \multicolumn{2}{c|}{ Y1.5 } \\
\cline { 2 - 12 } & F & \multicolumn{1}{c|}{$\%$} & F & \% & F & \% & F & \% & F & \multicolumn{1}{|c|}{} \\
\hline Sangat setuju & 15 & $30 \%$ & 16 & $32 \%$ & 16 & $32 \%$ & 12 & $24 \%$ & 3 & $6 \%$ \\
\hline Setuju & 31 & $32 \%$ & 31 & $62 \%$ & 32 & $64 \%$ & 31 & $62 \%$ & 45 & $90 \%$ \\
\hline Netral & 4 & $8 \%$ & 3 & $6 \%$ & 2 & $4 \%$ & 7 & $14 \%$ & 2 & $4 \%$ \\
\hline Tidak setuju & 0 & $0 \%$ & 0 & $0 \%$ & 0 & $0 \%$ & 0 & $0 \%$ & 0 & $0 \%$ \\
\hline Sangat tidak setuju & 0 & $0 \%$ & 0 & $0 \%$ & 0 & $0 \%$ & 0 & $0 \%$ & 0 & $0 \%$ \\
\hline Jumlah & 50 & $100 \%$ & 50 & $100 \%$ & 50 & $100 \%$ & 50 & $100 \%$ & 50 & $100 \%$ \\
\hline Modus & 4 & & 4 & & 4 & & 4 & & 4 & \\
\hline
\end{tabular}

Sumber: Lampiran distribusi frekuensi

Analisis linier regrasi berganda digunakan untuk melihat pengaruh dari dua variabel bebas atau lebih terhadap satu variabel terikat. Variabel bebas dalam penelian ini adalah motivasi kerja (X1), kepuasan kerja (X2), komitmen kerja (X3), sedangkan variabel terikatnya adalah kinerja pegawai (Y). Di bawah ini akan disajikan hasil perhitungan regresi liner berganda dengan bantuan software SPSS ver 21 .

Tabel 4.7 Hasil Analisis Regrasi Berganda

\begin{tabular}{|l|l|l|l|l|}
\hline Variabel & $\begin{array}{c}\text { Koefisien } \\
\text { regresi }\end{array}$ & $\begin{array}{c}\text { Standart } \\
\text { error }\end{array}$ & $\begin{array}{c}\mathrm{t} \\
\text { hitung }\end{array}$ & Sig \\
\hline $\begin{array}{l}\text { Motivasi } \\
\text { kerja (X1) }\end{array}$ & 0,333 & 0,114 & 2,921 & 0,005 \\
\hline $\begin{array}{l}\text { Kepuasan } \\
\text { kerja (X2) }\end{array}$ & 0,303 & 0,106 & 2,842 & 0,007 \\
\hline $\begin{array}{l}\text { Kepuasan } \\
\text { kerja (X2) }\end{array}$ & 0,289 & 0,109 & 2,664 & 0,011 \\
\hline
\end{tabular}

\section{Sumber pengujian regresi diolah.}

Constanta: 1,776

Koefisien determinasi $\left(\mathrm{R}^{2}\right)$ : 0,747

Multiple corelation (R): 0,865

$\mathrm{f}_{\text {hitung }}$ : 45,376 ( $\left.\operatorname{sig} 0,000\right)$

$\alpha \%: 5 \%$

Dari hasil perhitungan di atas maka didapatkan formula analisis regresi bergandanya adalah:
$\mathrm{Y}=\mathrm{a}+\mathrm{b} 1 \mathrm{X} 1+\mathrm{b} 2 \mathrm{X} 2+\mathrm{b} 3 \mathrm{X} 3$

nilainya menjadi

$\mathrm{Y}=1,776+0,333 \mathrm{X} 1+0,303 \mathrm{X} 2+0,289 \mathrm{X} 3$

Dari hasil perhitungan analisis regresi linier berganda yang dilakukan dengan bantuan software SPSS ver 21. Menunjukan bahwa pengaruh variabel independen yaitu yang terdiri dari motivasi kerja (X1), kepuasan kerja (X2), komitmen kerja (X3), berpengaruh terhadap kinerja pegawai (Y) tergolong kuat. Hal tersebut ditunjukan oleh hasil dari perhitungan nilai koefisien determinasi $\left(\mathrm{R}^{2}\right)$ sebesar 0,747. Artinya pengaruh motivasi kerja (X1), kepuasan kerja (X2), komitmen kerja (X3), terhadap kinerja pegawai (Y) berpengaruh sebesar 74,7\%. Sedangkan sisanya 25,3\% dipengaruhi oleh variabel lain selain variabel independen di dalam penelitian ini.

Koefisien korelasi berganda $\mathrm{R}$ (multilpe corelation) menggambarkan kuatnya hubungan antara variabel independen dengan variabel dependen sebesar 0,865. Artinya variabel dependen yang terdiri dari motivasi kerja (X1), kepuasan kerja (X2), komitmen kerja (X3) mempunyai hubungan yang kuat dengan kinerja pegawai (Y) sebesar $86,5 \%$.

Uji Hipotesis secara serantak digunakan untuk mengetahui faktor sub dimensi product display yang terdiri dari motivasi kerja (X1), kepuasan kerja (X2), komitmen kerja (X3) 
mempunyai hubungan yang kuat dengan kinerja pegawai (Y). Oleh karena itu maka digunakan perhitungan uji $\mathrm{F}$ (F-test) dengan kriteria pengujian sebagai berikut.

$\mathrm{H}_{0}$ diterima apabila $\mathrm{F}_{\text {hitung }} \leq \mathrm{F}_{\text {tabel. }}$.
$\mathrm{H}_{0}$ ditolak apabila $\mathrm{F}_{\text {hitung }}>\mathrm{F}_{\text {tabel }} \cdot$

Dari hasil perhitungan analisis regresi

berganda hasil pengaruh secara silmultan adalah sebagai berikut.

\section{Tabel 4.8 Hasil Perhitungan Uji F}

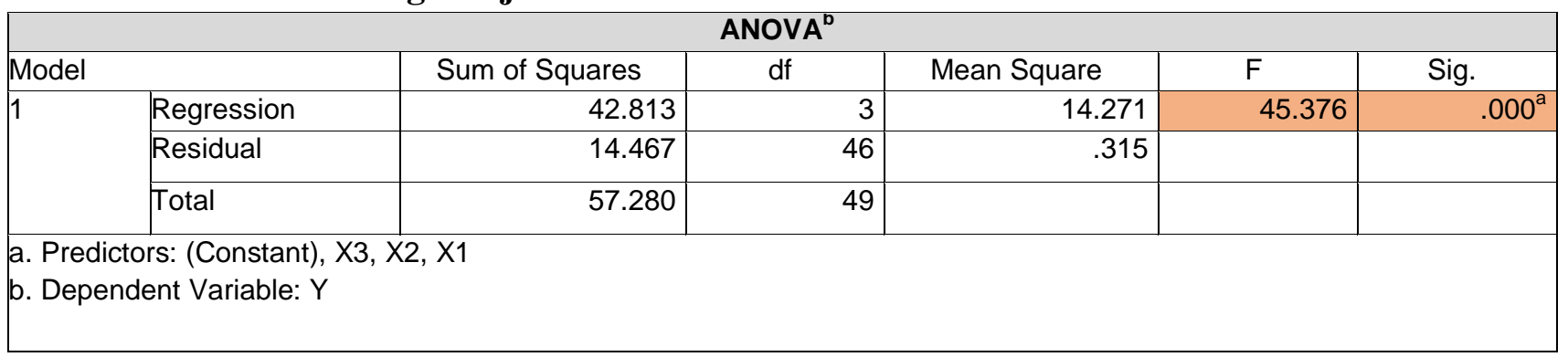

Dari tabel diatas menunjukkan nilai

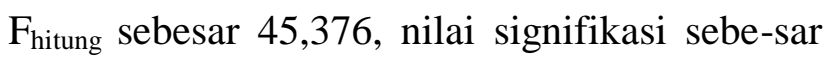
0,000. Nila $F_{\text {tabel }}$ sebesar 2,793948852. Sehingga dari perhitungan diatas dapat diketahui bahwa $\mathrm{F}_{\text {hitung }}>\mathrm{F}_{\text {tabel }}$ sehingga $\mathrm{H}_{0}$ ditolak dan $\mathrm{H}_{\mathrm{a}}$ diterima.dengan nilai 45,376>2,793948852 maka Ha diterima. Dengan demikian dapat dikatakan bahwa secara simultan motivasi kerja (X1), kepuasan kerja (X2), komitmen kerja (X3) mempunyai pengaruh terhadap kinerja pegawai (Y).

Uji $\mathrm{t}$ digunakan untuk mengetahui pengaruh masing-masing variabel indepen-den, yaitu variabel secara parsial motivasi kerja (X1), kepuasan kerja (X2), komitmen kerja (X3) terhadap kinerja pegawai (Y). di bawah ini adalah perhitungan uji $\mathrm{t}$ dengan bantuan software SPSS ver 21 .

Tabel 4.9 Hasil Perhitungan Uji-t

\begin{tabular}{|c|c|c|c|c|c|c|c|}
\hline \multicolumn{8}{|c|}{ Coefficients $^{a}$} \\
\hline \multirow[b]{2}{*}{ Model } & \multicolumn{2}{|c|}{ Unstandardized Coefficients } & \multirow{2}{*}{$\begin{array}{c}\text { Standardized Coefficients } \\
\text { Beta }\end{array}$} & \multirow[b]{2}{*}{$t$} & \multirow[b]{2}{*}{ Sig. } & \multicolumn{2}{|c|}{ Collinearity Statistics } \\
\hline & B & Std. Error & & & & Tolerance & VIF \\
\hline 1 (Constant) & 1.776 & 1.653 & & 1.074 & .288 & & \\
\hline $\mathrm{X} 1$ & .333 & .114 & .342 & 2.921 & .005 & .400 & 2.498 \\
\hline $\mathrm{X} 2$ & .303 & .106 & .332 & 2.842 & .007 & .403 & 2.483 \\
\hline X3 & .289 & .109 & .292 & 2.664 & .011 & .458 & 2.183 \\
\hline Dependent & riable: Y & & & & & & \\
\hline
\end{tabular}

Dari data di atas bisa diketahui bahwa nilai signifikansi (Sig.) untuk X1 nilainya adalah 0,005 , nilai signifikansi untuk X2 adalah 0,007 sedangkan nilai signifikansi untuk X3 adalah 0,011 . Nilai signifikansi yang berada di bawah atau sama dengan nilai alfa $5 \%(0,05)$ atau $(0,050)$ maka hal ini menunjukkan bahwa ada pengaruh, jika nilai signifikansi berada di atas nilai alfa maka bisa dikatakan bahwa tidak ada pengaruh. Nilai signifikan si dari $\mathrm{X} 1$ adalah 0,005 , nilai ini berada di bawah atau sama dengan 0,05 atau signifikansi X1 $\leq 0,05$, maka bisa disimpulkan bahwa variabel motivasi kerja (X1) berpengaruh terhadap kinerja pegawai (Y). Nilai signifikansi dari X2 adalah 0,007 nilainya juga berada di bawah alfa atau di atas 0,05 , atau bisa juga dikatakan bahwa 0,007 niainya kurang dari 0,05 artinya adalah kepuasan kerja (X2) 
secara parsial berpengaruh signifikan terhadap kinerja pegawai (Y). Nilai signifikansi dari komitmen kerja (X3) adalah 0,011 nilainya berada di bawah 0,05 , atau bisa juga dikatakan bahwa 0,011 niainya kurang dari 0,05 artinya adalah komitmen kerja (X3) secara parsial berpengaruh signifikan terhadap kinerja pegawai (Y).

\section{KESIMPULAN DAN SARAN}

Berdasarkan hasil penelitian maka kesimpulan dari penelitian ini adalah:

1. Secara parsial atau sendiri-sendiri antara variabel motivasi kerja (X1), kepuasan kerja (X2) dan komitmen terhadap (X3) tidak semuanya berpengaruh secara signifikan terhadap kinerja pegawai (Y) pada Sekolah Menengah Kejuruan Muhammadiyah 7 Gondanglegi Kabupaten Malang.

2. Ada pengaruh secara simultan atau bersamasama antara variabel motivasi kerja (X1), kepuasan kerja (X2) dan komitmen terhadap (X3) terhadap kinerja pegawai (Y) pada Sekolah Menengah Kejuruan Muhammadiyah 7 Gondanglegi Kabupaten Malang. Besar pengaruh dari ketiga variabel tersebut terhadap kinerja pegawai (Y) adalah $74,7 \%$ sedangkan sisanya $25,3 \%$ dipengaruhi oleh variabel lain.

Adapun saran di dalam penelitian ini bahwa variabel motivasi kerja, kepuasan kerja dan komitmen secara parsial tidak semuanya berpengaruh terhadap kinerja pegawai. Jika keadaannya memang seperti itu maka sebaiknya pimpinan atau atasan harus memperhatikan hal ini.

Penelitian dapat dijadikan pijakan untuk meningkatkan kinerja pegawai yaitu dengan ditingkatkan pelatihan-pelatihan untuk meningkatkan motivasi kerja. Dengan meningkatnya motivasi kerja maka akan meningkatkan kinerja pegawai, karena secara parsial motivasi kerja berpengaruh terhadap kinerja pegawai. Sedangkan kepuasan kerja dan komitmen kerja secara signifikan tidak berpengaruh terhadap kinerja pegawai, Jadi kepuasan kerja dan komitmen kerja tidak terlalu harus diperhatikan oleh pimpinan karena tidak berpengaruh secara parsial terhadap kinerja pegawai.

\section{DAFTAR PUSTAKA}

Alwi, Syafaruddin. 2001. Manajemen Sumber Daya Manusia, Strategi Keunggulan Kompetitif. Yogyakarta: BPFE.

Atmosoeprapto, Kisdarto. 2002. Menuju Sumber

Daya Manusia Berdaya Dengan Kepemimpinan Efektif dan Menejemen Efisien. Jakarta: PT Elex Media Komputindo.

Gibson, James L, John M.Ivancevich Jr. 2000.

Organisasi dan Manajemen; Perilaku Struktur, Proses, alih bahasa Djoerban Wahid. Jakarta: Erlangga.

Fathoni, Abdurrahmad, 2006. Organisasi dan Manajemen Sumber Daya Manusia. Cetakan Pertama. Jakarta, Penerbit PT Rineka Cipta.

Handoko, T. Hani. 2001, Manajemen Personalia dan Sumber Daya Manusia. Edisi Kedua. Yogyakarta:BPFE.

Hasibuan, Melayu SP, 2005. Manajemen Sumber Daya Manusia, Edisi Revisi, Cetakan Keenam, Jakarta, Penerbit Bumi Aksara.

Kuswadi, 2004. Cara Mengukur Kepuasan Karyawan, Penerbit PT Elex Media Jakarta, Komputindo.

Luthans, F. 1995. Organizational Behavior. Mc. Graw Hill.

Mangkunegara, A.Anwar Prabu, 2006, Manajemen Sumber Daya Manusia Bandung:Remaja Rosdakarya.

Mathis, L. Robert dan Jackson. H. John, 2001. Manajemen Sumber Daya Manusia. 
Edisi Pertama Buku I. Jakarta:Salemba Empat.

Mowday R T, 1982, Employ Organization Linkages: The Psychology of Commitment Abstein, and Turn Over, Academic,inc. London.

Mulyadi. 2001 Balanced Score Card. Alat Menejemen Kontemporer Untuk Peliput Ganda Kinerja Keuangan Perusahaan. Jakarta: Salemba Empat.

Robins, Stephen P, 2003, Perilaku Organisasi. Buku I, Edisi Indonesia. Jakarta: Indeks.

Robbins, Stephen P, 2006. Perilaku Organisasi, Jilid Kedua, Edisi Kesepuluh, Jakarta, Penerbit Prenhallindo.

Rivai, Veithzal, 2006. Manajemen Sumber Daya Manusia untuk Perusahaan, dari Teori ke Praktek. Edisi Pertama.Cetakan Ketiga. Jakarta:Raja Grafindo Persada.

Sedarmayanti. 2007, Manajemen Sumber Daya Manusia. Cetakan Pertama. Bandung:Refika Aditama.

Sutrisno, 2009. Manajemen Sumber Daya Manusia, Edisi Pertama, Cetakan Pertama, Jakarta, Penerbit Kencana Prenada Media. 